IZA DP No. 10155

Income Inequality and Well-Being in the U.S.:

Evidence of Geographic-Scale- and Measure-Dependence

John Ifcher

Homa Zarghamee

Carol Graham

August 2016 


\title{
Income Inequality and Well-Being in the U.S.: Evidence of Geographic-Scale- and Measure-Dependence
}

\author{
John Ifcher \\ Santa Clara University \\ and IZA \\ Homa Zarghamee \\ Barnard College \\ Carol Graham \\ Brookings Institution \\ and IZA
}

\section{Discussion Paper No. 10155 \\ August 2016}

\author{
IZA \\ P.O. Box 7240 \\ 53072 Bonn \\ Germany \\ Phone: +49-228-3894-0 \\ Fax: +49-228-3894-180 \\ E-mail: iza@iza.org
}

Any opinions expressed here are those of the author(s) and not those of IZA. Research published in this series may include views on policy, but the institute itself takes no institutional policy positions. The IZA research network is committed to the IZA Guiding Principles of Research Integrity.

The Institute for the Study of Labor (IZA) in Bonn is a local and virtual international research center and a place of communication between science, politics and business. IZA is an independent nonprofit organization supported by Deutsche Post Foundation. The center is associated with the University of Bonn and offers a stimulating research environment through its international network, workshops and conferences, data service, project support, research visits and doctoral program. IZA engages in (i) original and internationally competitive research in all fields of labor economics, (ii) development of policy concepts, and (iii) dissemination of research results and concepts to the interested public.

IZA Discussion Papers often represent preliminary work and are circulated to encourage discussion. Citation of such a paper should account for its provisional character. A revised version may be available directly from the author. 


\section{ABSTRACT \\ Income Inequality and Well-Being in the U.S.: Evidence of Geographic-Scale- and Measure-Dependence}

U.S. income inequality has risen dramatically in recent decades. Researchers consistently find that greater income inequality measured at the state or national level is associated with diminished subjective well-being (SWB) in the U.S. We conduct the first multi-scale analysis (i.e., at the ZIP-code, MSA, and state levels) of the inequality-SWB relationship using SWB data from the U.S. Gallup Healthways Well-Being Index and income inequality data from the American Community Survey. We use the rich set of well-being measures afforded by the dataset (evaluative, positive- and negative-affective hedonic, and health measures) to examine the consistency of the relationship. We find that the relationship is both scaledependent and measure-dependent: income inequality is SWB-diminishing in large regions for all measures, SWB-diminishing in small regions for negative-affective hedonic measures, and SWB-improving in small regions for most other measures. Lastly, we find that taking all regions together, the net relationship between income inequality and SWB is negative.

JEL Classification: D3, I14, D6

Keywords: $\quad$ subjective well-being, income inequality, happiness, distribution of income, health, scale-dependence, measure-dependence

Corresponding author:

John Ifcher

Department of Economics

Santa Clara University

500 El Camino Real

Santa Clara, CA 95053

USA

E-mail: jifcher@scu.edu 


\section{Introduction}

U.S. income inequality has increased dramatically in recent decades. From 1970 to 2014 , the Gini index increased 23 percent from 0.39 to 0.48 , and the income share of the top one percent of households increased 133 percent from 0.09 to 0.21 (DeNavas-Walt \& Proctor, 2015; Piketty \& Saez, 2014). This rise has captured the attention of researchers, policy makers, and the public alike. In 2013, the World Bank Group set the reduction of inequality as a mission goal for the first time. As of January 2015, Thomas Piketty's 2014 book, "Capital in the Twenty-First Century," had sold over 1.5 million copies, a record for the Harvard University Press. The former presidential candidate Bernie Sanders made rising income inequality a central issue in his campaign. The Occupy Wall Street protests popularized the meme, "The $1 \%$."

This recent focus assumes income inequality to be a societal problem; indeed President Barack Obama called it the "defining challenge of our time." However, economists do not have a well-established normative model identifying an "optimal" level of income inequality, and our understanding of the impact of income inequality is incomplete. Researchers have attempted to identify the relationship between income inequality and well-being (WB) using subjective well-being (SWB) measures from large-scale national and international surveys; SWB is increasingly used in public policy and economic analyses, with some countries (e.g., Bhutan, Britain, and France) now including SWB metrics in official statistics (Diener et al., 2009; Di Tella \& MacCulloch, 2006; O'Donnell, 2013; Stiglitz et al., 2010; Stone \& Mackie, 2013).

In Western countries, a negative inequality-SWB relationship is consistently identified. A feature of the extant literature is that the inequality-SWB relationship has only been identified using income inequality measured in large regions (e.g., states and countries). The literature on the relationship between neighbors' income and SWB has found that the sign of the relationship can depend on the scale of the region at which neighbors' income is considered. Numerous studies have found that the neighbors-income-SWB relationship is positive for small regions and negative for large regions (Brodeur \& Fleche, 2016; Clark et al., 2009; Deaton \& Stone, 2013; Graham \& Felton, 2006; Ifcher et al., 2016; Kingdon \& Knight, 2007).

We contribute to the literature by conducting, to our knowledge, the first multi-scale analysis of the inequality-SWB relationship. Specifically, we use SWB data from the U.S. Gallup Healthways Well-Being Index (GHWBI) and income inequality data from the American Community Survey (ACS) to estimate the inequality-SWB relationship separately at the ZIP-code, MSA, and state levels. Further, we use the rich set of WB measures afforded by the GHWBI (evaluative SWB, positive and negative hedonic SWB, and health) to examine the consistency of the relationship. We find that the relationship is both scale-dependent and measure-dependent: income inequality is SWB-diminishing in large regions for all measures, SWB-diminishing in small regions for negativeaffective hedonic measures, and SWB-improving in small regions for most other measures. Additionally, we conduct analyses to determine the predicted contribution to SWB of moving from perfect equality to average inequality at all scales and find that the 
net relationship is consistently negative. This suggests that, although we identify circumstances under which income inequality can be SWB-improving, it should be considered a societal problem overall.

\section{Literature review}

Although neo-classical economic models do not include others' consumption as an argument of the utility function, strong empirical evidence suggests that WB is affected by others' consumption. Empirical analyses of the relationship between others' income and SWB is divided into two lines of inquiry. ${ }^{1}$ The bulk of this literature examines the relationship between measures of central tendency of a reference group's income distribution and SWB (see Ifcher et al. (2016) for a review of the neighbors-income-SWB literature). A smaller literature considers the relationship between measures of dispersion and SWB, which is the focus of this paper (see Schneider (2015) for a review of the inequality-SWB literature).

For the U.S., a negative relationship between income inequality and SWB has been empirically identified. In this literature, SWB is almost exclusively measured "evaluatively," that is, with survey items asking respondents to report their evaluations of their lives as a whole (e.g., the General Social Survey asks, "Taking things all together, how would you say things are these days - would you say that you're very happy, pretty happy, or not too happy these days?"). Income inequality is usually measured using the Gini index but has also been measured using income shares of specific income-segments (e.g., deciles). The negative inequality-SWB relationship in the U.S. has been identified both across states (i.e., more unequal states have lower SWB; e.g., Alesina et al., 2004) and over time at the national level (i.e., when the U.S. income distribution is more unequal, U.S. SWB is lower; e.g., Oishi et al., 2011). Similar results obtain within and across Western countries (Alesina et al., 2004; Delhey \& Dragolov, 2014; Fahey \& Smyth, 2004; Hagerty, 2000; Layte, 2012; Schwarze \& Harpfer, 2007; Tomes, 1986). ${ }^{2}$

Various explanations have been offered for the negative inequality-SWB relationship, chief among them being inequity aversion (Alesina et al, 2004; Senik, 2009; Thurow, 1971). Other explanations are that inequality increases crime, violence, and political conflict (Diener et al, 1995; Haller \& Hadler, 2006); reduces social capital and trust (Brush, 2007; Choe, 2008; Costa \& Kahn, 2003; Hsieh \& Pugh, 1993; Kawachi \& Kennedy, 1999; Kelly, 2000; Savolainen, 2000); and reduces the effectiveness of public institutions (Veenhoven, 1995).

When using international datasets that include both non-Western and Western countries, the inequality-SWB relationship is often positive or insignificant for the former and

\footnotetext{
${ }^{1}$ Concerns about the validity and reliability of SWB metrics have been addressed at length elsewhere, and we refer interested readers to the corresponding literature. SWB metrics have been shown to be psychometrically sound, internally consistent and comparable across individuals, over time, and for different levels of economic development (Diener et al., 1999; Frey \& Stutzer, 2002; Helliwell et al., 2010; Krueger \& Schkade, 2008).

2 The only positive inequality-SWB relationship identified using data from a Western country is Clark (2003).
} 
negative for the latter. For example, Helliwell \& Huang (2008), Ott (2005), and Schyns (2002) identify a positive inequality-SWB relationship using the World Values Survey. Subgroup analyses yield that the positive relationship holds for Latin American, poor, and poorly governed countries, while a negative relationship obtains for non-LatinAmerican countries. Using the World Database of Happiness, Berg \& Veenhoven (2010) identify a positive inequality-SWB relationship in Latin America, Eastern Europe, and Asia; no significant relationship in Africa; and a negative relationship in Western countries. Graham \& Felton (2006) find no significant inequality-SWB relationship in Latin America. Finally, Knight et al. (2009) identify a positive inequality-SWB relationship across counties in China.

The explanation usually offered for the positive inequality-SWB relationship is the "tunnel effect," whereby, in periods of rapid development, increasing inequality may be taken as signal that own-income will soon rise (Hirschman \& Rothschild, 1971). Other explanations are that inequality increases the diversity of lifestyle and consumption choice-sets, or that inequality is a byproduct of minimal government intrusion and more personal freedom (Berg \& Veenhoven, 2010).

In the inequality-SWB literature, inequality has only been measured in large regions (e.g., states and countries). The smallest regions considered are Canadian Federal Election Districts (avg. pop. $=82,000$ ) in Tomes $(1986)$. In contrast, the neighbors-income-SWB literature has considered both large and small regions (e.g., ZIP codes). These multi-scale analyses have found that the neighbors-income-SWB relationship is scale-dependent: positive for small regions and negative for large regions (Brodeur \& Fleche, 2016; Clark et al., 2009; Deaton \& Stone, 2013; Ifcher et al., 2016; Kingdon \& Knight, 2007). This literature suggests that the pattern emerges due to the relative magnitudes of mediators in the neighbors-income-SWB relationship; for example, public goods may dominate other mediators in small regions, while cost-of-living may dominate in large regions.

We contribute to the literature by conducting, to our knowledge, the first multi-scale analysis of the inequality-SWB relationship. Specifically, we attempt to identify the relationship between SWB and income inequality measured separately at the ZIP-code, MSA, and state levels. Such an exercise is important for several reasons. First, restricting analyses to large regions may obscure the fundamental nature of the inequality-SWB relationship; that is, whether SWB is associated with inequality in large-regions, smallregions, or both. For example, a negative relationship identified using large regions cannot speak to whether there is a small-region inequality-SWB relationship; conversely, it may be that the negative relationship identified using large regions is driven by smallregion inequality (and misattributed to large regions due to the correlation of small- and large-region inequalities). Second, it may be that, as in the neighbors-income-SWB literature, the relative magnitudes of mediators of the inequality-SWB relationship are scale-dependent. For example, it may be that the positive impact of income inequality on the choice-set may dominate other mediators in small regions, while inequity aversion may dominate in large regions. Our analysis allows for the identification of a more nuanced and potentially bifurcated relationship between income inequality and SWB. 
There is increasing consensus among scholars on the need to differentiate two distinct measurable dimensions of SWB: evaluative and hedonic. Evaluative SWB captures how people assess their lives or particular domains of their lives; it is typically measured on numerical scales corresponding to life satisfaction or happiness. Hedonic SWB captures the quality of individuals' experiences in their daily lives and their moods during those experiences; it is typically measured on a numerical scale corresponding to positive and/or negative affect during a relatively short time frame. ${ }^{3}$ The inequality-SWB relationship has been estimated using evaluative SWB measures. Two exceptions use both evaluative and "hedonic" SWB measures. Berg \& Veenhoven (2010) and Clark (2003) find consistent inequality-SWB results across evaluative and hedonic measures (i.e., the inequality-SWB relationship is not measure-dependent). Layte (2012) only uses a hedonic measure and identifies a negative inequality-SWB relationship in Europe, consistent with the literature using evaluative measures.

Our second contribution to the literature is to use a rich set of hedonic and health measures (in addition to evaluative measures) to examine the inequality-SWB relationship. This is important for two reasons. First, psychologists have shown that wellbeing and ill-being are not opposites (e.g., survey respondents often report high levels of both) and do not necessarily respond to circumstances symmetrically (Headey \& Wooden, 2004). The three inequality-SWB studies that use hedonic measures construct scalars from responses to various questions assessing recent positive and negative affective and psychological states. As such, divergent relationships between income inequality and positive versus negative hedonic SWB cannot be identified. Second, identifying the inequality-SWB relationship using both evaluative and hedonic SWB measures allows for measure-dependent results, as has been found for both own and neighbors' income. Kahneman \& Deaton (2010) find a satiation point of $\$ 75,000$ in the own-income-SWB relationship using hedonic but not evaluative measures. Deaton \& Stone (2013) identify a negative neighbors-income-SWB relationship in small regions using hedonic measures and a positive relationship using evaluative measures.

\section{Empirical strategy}

\subsection{Econometrics}

We begin with a brief presentation of a standard SWB equation:

$$
y_{\mathrm{i}}=\alpha_{0}+\alpha_{1} X_{\mathrm{i}}+\varepsilon_{\mathrm{i}}
$$

for $i=1, \ldots, I$, where $i$ indexes individuals. The dependent variable $y_{i}$ is the SWB of the $i^{\text {th }}$ respondent; $X_{i}$ is a vector of SWB-correlates of the $i^{\text {th }}$ respondent, including

\footnotetext{
${ }^{3}$ It should be noted that there is a third dimension that has recently emerged as a distinct category: eudemonic SWB assesses the extent to which individuals have purpose or meaning in their lives. For a detailed discussion of the distinct dimensions of SWB metrics and the corresponding report for the National Academy of Sciences, see Stone \& Mackie (2013).
} 
demographic and socioeconomic characteristics; and $\varepsilon_{\mathrm{i}}$ captures unobserved characteristics and measurement error (Graham, 2005). ${ }^{4}$

In the context of this paper, the standard equation can be modified to explicitly illustrate the coefficients on regional income inequality as well as on regional income and own income:

$$
y_{i}=\beta_{0}+\beta_{1} \text { Gini }_{i}+\beta_{2} \ln \left(\text { MedianInc }_{i}\right)+\beta_{3} \ln \left(\text { OwnInc }_{i}\right)+\mathrm{D}_{i} \gamma+\mu_{t}+\varepsilon i .
$$

The independent variable Gini $i_{i}$ is the income inequality for the $i^{t h}$ respondent's region as measured by the Gini index; MedianInc $i$ is the $i^{\text {th }}$ respondent's regional median income; and $O w n I n c_{\mathrm{i}}$ is the $i^{\text {th }}$ respondent's self-reported income. $D_{i}$ is a vector of SWB-correlates for the $i^{\text {th }}$ respondent, including demographic and socioeconomic characteristics: gender, age, race, education, employment, marital status, and parental status. The model also includes time (day, month, and year of interview) fixed effects $\mu_{t}$.

The coefficient of interest $\beta_{1}$ captures the relationship between regional income inequality and SWB, holding constant regional and own income. A positive (negative) estimate of $\beta_{1}$ indicates that SWB is increasing (decreasing) in income inequality. We measure the $i^{\text {th }}$ respondent's regional Gini index and median income at three levels: ZIPcode $(\sim 7,500$ people per ZIP code, range $1-100 \mathrm{~K})$, MSA $(\sim 850,000$ people per MSA, range $50 \mathrm{~K}-20 \mathrm{M})$, and state $(\sim 6 \mathrm{M}$ per state, range $0.5 \mathrm{M}-38 \mathrm{M})$. Standard errors are adjusted for arbitrary forms of heteroskedasticity as well as the non-random clustering of observations by ZIP code.

\subsection{Data}

The GHWBI has conducted a telephone survey (landline or mobile) with approximately 1,000 U.S. inhabitants per day in repeated cross-sections since January 2008 using a stratified sampling technique. ${ }^{5}$ Our analysis uses data from 2011 through 2012, during which time 685,368 individuals were surveyed. Our final sample consists of 456,719 individuals; as explained below, observations missing necessary information were dropped. Summary statistics are presented in Table 1.

\subsubsection{Dependent variables}

Various measures of WB are used as dependent variables $y_{i}$. Our evaluative SWB measure is the Cantril ladder "best possible life" (BPL) index. The item reads: "Please imagine a ladder with steps numbered from 0 at the bottom to 10 at the top. The top of the ladder represents the best possible life for you, and the bottom of the ladder represents the worst possible life for you. On which step of the ladder would you say you personally

\footnotetext{
${ }^{4}$ In a previous version of the paper, a fourth level — counties $(\sim 100,000$ people per county $)$-was included; all results presented hold with the inclusion of county-level variables. County-level coefficients were always between ZIP-code and MSA-level coefficients, but more similar to MSA. As the inclusion of counties is not informative, we do not to include them for ease of analysis.

${ }^{5}$ Graham is an academic advisor to the GHWBI and in that capacity has access to the data.
} 
feel you stand at this time?" ${ }^{\prime 6}$ Our hedonic SWB measures are enjoyment, happiness, stress, and worry. For each, respondents are asked: "Did you experience the following feelings during a lot of the day yesterday? How about ?" An indicator variable is created for each.

We also consider well-being using various health measures. The first is a self-reported health measure that reads: "Would you say your own health, in general, is: poor, fair, good, very good, or excellent?" Possible answers are coded from 1 to 5, respectively. Second, respondents are asked: "Have you ever been told by a physician or nurse that you have any of the following: high blood pressure, high cholesterol, diabetes, depression, heart attack, asthma, or cancer?" An indicator variable is created for each of these diagnoses. Third, respondents are asked about various health-related behaviors, including current smoking, the number of days in the last week they exercised at least 30 minutes, and the number of days in the last week they ate at least five fruits or vegetables. Lastly, respondents reported their height and weight, allowing Body Mass Index (BMI) to be calculated.

\subsubsection{Independent variables}

ZIP-code, MSA, and state characteristics come from the U.S. Census Bureau's 2011 and 2012 ACS. The ACS is administered by mail to roughly 2,000,000 households per year and includes questions regarding demographic, economic, financial, housing, and social characteristics. The ACS reports ZIP-code, MSA, and state Gini indexes and median incomes that we then match to the GHWBI data. ${ }^{7}$ The ACS's ZIP-code Gini index and median income data are only available as five-year estimates (e.g., 2011 ZIP-code median income is the 2007-2011 median). This is not the case for MSA and state Gini indexes and median income. ${ }^{8}$

To measure own income, we use responses to the GHWBI item: "What is your total MONTHLY household income, before taxes? Please include income from wages and salaries, remittances from family members living elsewhere, farming, and all other sources." Eleven possible response-categories are included: under $\$ 60 ; \$ 60-\$ 499 ; \$ 500$ $\$ 999 ; \$ 1,000-\$ 1,999 ; \$ 2,000-\$ 2,999 ; \$ 3,000-\$ 3,999 ; \$ 4,000-\$ 4,999 ; \$ 5,000-\$ 7,499$; $\$ 7,500-\$ 9,999 ; \$ 10,000$ and over; and unknown. ${ }^{9}$ Respondents' annual household income variable is calculated as twelve times the midpoint of the corresponding monthlyincome category. All regressions include an indicator variable for top-coded income.

\footnotetext{
${ }^{6}$ Of the total sample, $0.5 \%$ had missing values for BPL or refused to respond to that item. Those observations were dropped.

${ }^{7}$ Median ZIP-code income was missing from the ACS for a small number of observations; these observations were dropped. Also, 141,175 (20.6\%) respondents did not live in an MSA; these observations were dropped.

8 As a robustness check, in analyses not shown, we use five-year estimates of MSA and state Gini indexes and median income and obtain the same results.

${ }^{9}$ Income data was missing for 109,642 (16\%) observations; these observations were dropped.
} 


\section{Results}

\subsection{Income inequality and SWB in large regions}

For comparability with the extant literature, we first consider large regions (here defined as MSAs and states) and use BPL as the dependent variable. Estimating equation (2) separately at the MSA- and state-levels ("single-scale model"), the Gini-index coefficients are both negative and significant (see Table 2). This indicates that, consistent with the literature pertaining to Western countries, income inequality in large regions is associated with diminished evaluative SWB. We repeat this analysis using as dependent variables hedonic SWB measures. With enjoyment and happiness (stress and worry), the MSA and state Gini-index coefficients are both negative (positive) and significant (see Table 2). In sum, we find a negative inequality-SWB relationship in large regions using both evaluative and hedonic SWB measures.

\subsection{Income inequality and SWB in small regions}

A contribution of this study is examining the inequality-SWB relationship in small regions (here defined as ZIP codes). As noted above, the next smallest region considered in the literature is roughly 100 (10) times more populous using U.S. (international) data. Estimating the single-scale model at the ZIP-code level using BPL as the dependent variable, the Gini-index coefficient is positive and significant (see Table 3 ). This indicates that income inequality in small regions is associated with improved evaluative SWB. That the relationship between income inequality and evaluative SWB is scaledependent (i.e., SWB-diminishing in large regions and SWB-improving in small regions) is also a novel contribution.

Using enjoyment and happiness as the dependent variables, the ZIP-code Gini-index coefficients are both insignificant (see Table 3). As with BPL, the relationships between income inequality and enjoyment and happiness are scale-dependent (i.e., SWBdiminishing in large regions and unrelated to SWB in small regions). In contrast, the ZIP-code Gini index coefficients using stress and worry are both positive and significant, indicating that the relationships between income inequality and both stress and worry are consistently SWB-diminishing in both large and small regions.

\subsection{Multi-scale model}

Given that the ZIP-code, MSA, and state Gini indexes are correlated (see Table 4), the Gini-index coefficients reported above may be confounded. For example, the observed state Gini-index coefficient could be the result of the relationship between the dependent variable and MSA income inequality, not state income inequality. In an attempt to separate and control for the simultaneous relationships, we estimate equation (2) with all three regions' Gini indexes and median incomes on the right hand side ("multi-scale model"). Moreover, the multi-scale model creates a "horse race" that may enable us to establish which level of regional income inequality is more strongly related to SWB. 
Estimating the multi-scale model with BPL as the dependent variable, the ZIP-code Giniindex coefficient is positive and significant, whereas both the MSA and state Gini-index coefficients are negative and significant (see Table 5). This pattern is the same as reported for BPL in the single-scale model. It warrants mention that the magnitude and significance of the ZIP-code and MSA Gini-index coefficients have increased in the multi-scale model, while the magnitude and significance of the state Gini-index coefficient have decreased. This indicates that the relationship between income inequality and evaluative SWB is stronger for ZIP-code and MSA than state income inequality.

The t-scores of the ZIP-code and MSA Gini-index coefficients are 10.3 and 17.5, respectively. BPL increases by $0.067(=0.065 * 1.027)$ steps and decreases by $0.046(=$ $0.031 *-1.489)$ steps over the ZIP-code and MSA Gini-index interquartile ranges. ${ }^{10}$ For comparison, a well-known correlate of BPL is unemployment, the coefficient of which is $-0.134(t=20.6)$. Thus, the magnitude of the change in BPL associated with spanning the ZIP-code (MSA) Gini-index interquartile range is approximately a half (third) of the change associated with unemployment.

It should also be noted that including the three Gini indexes in the same specification does not cause the standard errors to "blow up:" the corresponding standard errors in the multi-scale model are similar to those in the single-scale models. Thus, the multi-scale model estimates the inequality-SWB relationship for each region as precisely as the corresponding single-scale model, while also controlling for the potentially overlapping relationships between each region's income inequality and SWB; therefore, in subsequent analyses we use the multi-scale model as our main model.

Estimating the multi-scale model with enjoyment and happiness as dependent variables, the MSA and state Gini-index coefficients are negative and significant, as in the singlescale model (see Table 5). In contrast, the ZIP-code Gini-index coefficients are positive and significant, unlike in the single-scale models where they are insignificant. This suggests that after controlling for the negative relationship between income inequality and both enjoyment and happiness at the MSA- and state-levels, there is a positive relationship between ZIP-code income inequality and both enjoyment and happiness.

Estimating the multi-scale model with stress and worry as dependent variables, the ZIPcode and MSA Gini-index coefficients are positive and significant, as in the single-scale models (see Table 5). The magnitude and significance of state Gini-index coefficients are substantially diminished in the multi-scale model as compared to the single-scale models: the state-coefficient for stress is insignificant and the state-coefficient for worry is less than one-third its single-scale-model significance and magnitude. As with BPL, this indicates that the relationship between income inequality and both stress and worry is stronger for ZIP-code and MSA than state income inequality.

\footnotetext{
10 The interquartile range for the ZIP-code and MSA Gini indexes are 0.065 (from 0.390 to 0.455 ) and 0.031 (from 0.445 to 0.476 ), respectively.
} 
Not only does the multi-scale model enable some disentangling of the relationships between income inequality and SWB for nested regions, it also enables the estimation of a net relationship between income inequality and SWB. Specifically, we can calculate the predicted contribution to SWB of experiencing mean income inequality, as compared to

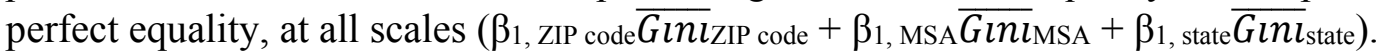
Such a calculation has the additional benefit of not arbitrarily privileging one regional scale over another. This calculation yields net relationships that are SWB-diminishing, with t-scores ranging from 7.1 to 14.6, for all five SWB-measures (see Table 5). This indicates that, although SWB may improve with income inequality in small regions, in net, income inequality is SWB-diminishing.

In sum, the multi-scale model improves upon single-scale-model analyses by controlling for the multi-scale regional inequalities in the estimation of each region's Gini-index coefficient. The multi-scale model reveals that the relationships between income inequality and BPL, enjoyment, and happiness are each scale-dependent: SWBdiminishing in large regions and SWB-improving in small regions. As in the single-scale models, the relationships between income inequality and both stress and worry seem to be consistent and SWB-diminishing in large and small regions. Estimation of the net multi-scale relationship indicates that income inequality is SWB-diminishing using all SWB measures.

\subsection{Other WB measures}

The GHWBI includes a rich set of WB measures, including domain-specific evaluative SWB measures (self-reported health, BPL in five years, satisfaction with city), ${ }^{11}$ disease diagnoses (asthma, cancer, depression, diabetes, heart attack, high blood pressure, and high cholesterol), and health-related behaviors (smoking, BMI, exercise, and healthy eating). We estimate the multi-scale model using each of these fourteen WB-measures as the dependent variable (see Table 6).

The ZIP-code Gini-index coefficients indicate that income inequality is significantly WBimproving for all fourteen measures, except that it is significantly SWB-diminishing for depression and insignificant for asthma and cancer. The state Gini-index coefficients indicate that income inequality is significantly WB-diminishing for all fourteen measures, except that it is significantly SWB-improving for depression and healthy eating, and insignificant for BMI, exercise, and BPL in five years. The MSA-level results and net relationships are mixed. It is worthy of note that, again, income inequality in small regions is predominantly WB-improving. Further, for all WB measures in Table 6, the relationship between income inequality and WB is scale-dependent.

\footnotetext{
${ }^{11}$ The BPL-in-five-years item immediately follows the BPL item in the GHWBI and reads, "On which step do you think you will stand about five years from now?" Possible responses range from 0 to 10 . The satisfaction-with-city item asks, "Are you satisfied or dissatisfied with the city or area where you live?" Possible responses are satisfied and dissatisfied.
} 


\subsection{Subgroup analyses}

To determine whether our main results are consistent across various subgroups, we estimate the multi-scale model and net relationships for the regional, demographic, and socioeconomic subgroups described in Table 7.

For tractability, in Table 8 we report the Gini-index coefficients only for subgroups in which systematic differences are identified; further, we suppress standard errors and only report results for BPL, enjoyment, and worry (the results using happiness and stress are similar to those using enjoyment and worry, respectively). Complete subgroup analyses are reported in Appendix A.

First, subgroup analysis for bottom and top ZIP-code Gini-index quartiles reveals that the inequality-SWB relationship is more strongly positive in the top than bottom quartile.

The baseline result that inequality is SWB-improving for BPL and enjoyment at the ZIPcode level holds for the top quartile; the ZIP-code Gini-index coefficients are insignificant for the bottom quartile. Moreover, the baseline result that inequality is SWB-diminishing for worry at the ZIP-code level holds for the bottom quartile; the ZIPcode Gini-index coefficient is insignificant for the top quartile. This suggests that the benefits of income inequality are less pronounced in more equal ZIP codes.

Second, subgroup analyses for bottom and top ZIP-code median, MSA median, and own income quartiles reveal that the baseline results are driven by the top income quartiles. For example, for bottom income quartiles, the relationship between inequality and BPL in large regions is diminished in magnitude and significance, and the net relationship between income inequality and BPL is in all cases insignificant. Similarly, for bottom income quartiles, the relationship between income inequality and enjoyment and worry in small regions is generally diminished in magnitude and significance, as are the net relationships between income inequality and enjoyment and worry. Similarly, in subgroup analyses, Alesina et al. (2004) found no inequality-SWB relationship for lowincome individuals in the U.S.; the authors attribute this to perceived economic mobility.

Lastly, subgroup analyses by race and educational attainment reveal that the baseline results are driven by whites and the highly educated. Most starkly, the inequality-SWB relationship is almost non-existent for blacks. Also, for individuals with low education, the baseline results that ZIP-code inequality is SWB-improving for enjoyment and SWBdiminishing for worry do not hold. The racial and educational disparities in the inequality-SWB relationship may be related to own-income disparities apparent in the GHWBI, as blacks have lower mean income than whites $(\$ 48,284$ versus $\$ 62,296)$ and individuals with low education have lower mean income than those with high education $(\$ 38,422$ versus $\$ 75,184)$.

\subsection{Other specifications}

Given the Gini index's sensitivity to the middle of the income distribution (see Atkinson, 1970), we examine the relationship between income inequality and SWB replacing the 
Gini index in the multi-scale model with measures of income inequality that focus on the tails of the income distribution: the income-share of the bottom quintile, top quintile, and top five percent. In each of the three specifications, the main results hold: income inequality is SWB-improving for small regions and SWB-diminishing in large regions using BPL, enjoyment, and happiness as the dependent variable; and income inequality is SWB-diminishing in both small and large regions using stress and worry as the dependent variable (see Table 9).

In an additional specification, we estimate the multi-scale model including as covariates the ZIP-code, MSA, and state poverty and unemployment rates. The main results hold, indicating that the relationship between income inequality and SWB is not driven by regional poverty and unemployment rates. Finally, we restrict the sample to ZIP-codes with at least 30 and 60 respondents and the main results hold, indicating that our results are not driven by small ZIP codes where inequality might be more salient.

\section{Discussion}

The current paper makes two novel contributions to the inequality-SWB literature. First, we estimate the inequality-SWB relationship in nested regions: ZIP codes, MSAs, and states. Second, we use a rich set of WB measures (evaluative, positive- and negativeaffective hedonic, and health measures) to examine the generalizability of the identified relationships. Replicating the results from the extant literature, we find a negative inequality-SWB relationship in large regions using evaluative measures. When we extend the analysis to small regions, which have not been studied in the literature, we find a positive relationship, indicating that the inequality-SWB relationship is scaledependent. Further, we find that our evaluative results extend to positive-affective hedonic measures (enjoyment and happiness) in both small and large regions, and to most health measures in small regions. Lastly, for negative-affective hedonic measures (stress and worry), the bifurcation of the inequality-SWB relationship does not hold: income inequality is consistently SWB-diminishing in both small and large regions.

Our small-region result, that income inequality is SWB-improving, is novel in a Westerncountry context. Positive inequality-SWB relationships have generally been identified in non-Western countries. The primary explanation for such results is the tunnel effect, whereby, increasing inequality may be taken as a signal that own-income will rise in periods of rapid development. Our subgroup analyses find that the inequality-SWB relationship is weaker for low- than high-income respondents. As such, it is unlikely that the results are driven by the tunnel effect in the U.S. As noted above, in the literature, two additional potential explanations for a positive inequality-SWB relationship have been proposed: that inequality increases the diversity of lifestyle and consumption choice-sets, and that inequality is a byproduct of minimal government intrusion and more personal freedom. Another potential explanation is suggested by Butler (2016), who finds that individuals randomly assigned to a low-pay treatment in an economic experiment are more likely to believe that they performed poorly than those assigned to a high-pay treatment, despite no difference in performance. This might suggest that low-income respondents believe that their low income is deserved and therefore are less sensitive to 
income inequality. Lastly, it may be that the inequality-SWB relationship is weaker for low-income respondents because they are less aware of or sensitive to income inequality than high-income respondents.

The literature review discusses mediators for the inequality-SWB relationship. Recall that negative mediators include inequity aversion; that inequality increases crime, violence, and political conflict; and that inequality reduces social capital, trust, and the effectiveness of public institutions; and positive mediators include the tunnel effect, that inequality expands the choice-set, and that inequality indicates minimal government intrusion. Importantly, all of these mediators may be operant concurrently. Thus, a positive (negative) Gini coefficient simply indicates that the positive (negative) mediators dominate. To identify specific mediators is beyond the scope of this paper. Further, the scale-dependence of the inequality-SWB relationship indicates that the mediators are scale-dependent as well.

Lastly, the results illustrate the importance of having a rich set of WB measures, as the positive inequality-SWB relationship identified in small regions using most WB measures does not hold for negative-affective hedonic measures. Thus, income inequality is both SWB-diminishing and SWB-improving in small regions: increasing stress and worry and increasing BPL, enjoyment, happiness and most health measures. This suggests that for different WB measures different mediators are dominant. 
References:

Alesina, A. Di Tella, R., \& MacCulloch, R. (2004). Inequality and happiness: Are Europeans and Americans different? Journal of Public Economics, 88 (9-10): 2009-2042.

Atkinson, A.B. (1970). On the measurement of inequality. Journal of Economic Theory, 2: $244-263$.

Berg, M., \& Veenhoven, R. (2010). Income inequality and happiness in 119 nations. In B. Greve (Ed.), Happiness and social policy in Europe (pp. 174-194). Cheltenham: Edward Elgar.

Brodeur, A., \& Fleche, S. (2015). Neighbors, Income and Well-Being: Evidence from a Multi-scale Analysis. Working Paper.

Brush, J. (2007). Does income inequality lead to more crime? A comparison of crosssectional and time-series analyses of United States counties. Economics Letters, 96(2): 264-268.

Butler, J.V. (2016). Inequality and relative ability beliefs. The Economic Journal, 126(593): 907-948.

Choe, J. (2008). Income inequality and crime in the United States. Economics Letters, 101(1): 31-33.

Clark, A.E. (2003). Inequality-aversion and income mobility: A direct test. Mimeo. DELTA, Paris.

Clark, A.E., Kristensen, N., \& Westergard-Neilsen, N. (2009). Economic Satisfaction and Income Rank in Small Neighbourhoods. Journal of the European Economic Association, 7(2-3): 519-527.

Costa, D. L., \& Kahn, M. E. (2003). Understanding the American Decline in Social Capital, 1952-1998. Kyklos, 56(1): 17-46.

Deaton, A., \& Stone, A.A. (2013). Two happiness puzzles. American Economic Review, 103(3): 591-597.

DeNavas-Walt, C., \& Proctor, B.D. (2015). Income and poverty in the United States: 2014. In U.S. Census Bureau, Current Population Reports (pp. 60-252) Washington D.C.: U.S. Government Printing Office.

Delhey, J., \& Dragolov, G. (2014). Why inequality makes europeans less happy: The role of distrust, status anxiety, and perceived conflict. European Sociological Review, 30(2): $151-165$. 
Diener, E., Diener, M., \& Diener, C. (1995). Factors predicting the subjective well-being of nations. Journal of Personality and Social Psychology, 69(5): 851-864.

Diener, E., Suh, E.M., Lucas, R.E., \& Smith, H.L. (1999). Subjective well-being: Three decades of progress. Psychological Bulletin, 125(2): 276-302.

Diener, E., Lucas, R., Schimmack, U., \& Helliwell, J. (2009). Well-Being for Public Policy. Oxford: Oxford University Press.

Di Tella, R., \& MacCulloch, R. (2006). Some uses of happiness data in economics. Journal of Economic Perspectives, 20(1): 25-46.

Fahey, T., \& Smyth, E. (2004). The link between subjective well-being and objective conditions in European societies. In W. A. Arts \& L. Halman (Eds.), European values at the turn of the millennium (pp. 57-80). Leiden: Brill.

Frey, B.S., \& Stutzer, A. (2002). What can economists learn from happiness research? Journal of Economic Literature, 40(2): 402-435.

Graham, C. (2005). The economics of happiness. World Economics, 6(3): 41-55.

Graham, C., \& Felton, A. (2006). Inequality and happiness: insights from Latin America. Journal of Economic Inequality, 4(1): 107-122.

Hagerty, M. R. (2000). Social comparisons of income in one's community: Evidence from national surveys of income and happiness. Journal of Personality and Social Psychology, 78(4): 764-771.

Haller, M., \& Hadler, M. (2006). How social relations and structures can produce happiness and unhappiness: An international comparative analysis. Social Indicators Research, 75(2): 169-216.

Headey, B.W., \& Wooden, M. (2004). The effects of wealth and income on subjective well-being and ill-being. The Economic Record, 80: S24-S33.

Helliwell, J., \& Huang, H. (2008). How's your government? International evidence linking good government and well-being. British Journal of Political Science, 38: 595619.

Helliwell, J.F., Barrington-Leigh, C.P., Harris, A., \& Huang, Haifang. (2010). International Evidence on the Social Context of Well-Being. In E. Diener, J.F. Helliwell, \& D. Kahneman, eds. International Differences in Well-Being. Oxford: Oxford University Press.

Hirschman, A.O., \& Rothschild, M. (1973). The Changing tolerance for income inequality economic development. Quarterly Journal of Economics, 87(4): 544-566. 
Hsieh, C.-C., \& Pugh, M.D. (1993). Poverty, income inequality, and violent crime: A meta-analysis of recent aggregate data studies. Criminal Justice Review, 18(3): 182-202.

Ifcher, J., Zarghamee, H., \& Graham, C. (2016) Local Neighbors as Positives, Regional Neighbors as Negatives: Competing Channels in the Relationship between Others' Income, Health, and Happiness. IZA Discussion Paper 9934.

Kahneman, D., \& Deaton, A. (2010). High income improves evaluation of life but not emotional well-being. Proceedings of the National Academy of Sciences, 107(38): 1648916493.

Kawachi, I., Kennedy, B.P., Lochner, K., \& Prothrow-Stith, D. (1997). Social and mortality. American Journal of Public Health, 87(9): 1491-1498.

Kelly, M. (2000). Inequality and crime. Review of Economics and Statistics, 82(4): 530 539.

Kingdon, G. G., \& Knight, J. (2007). Community, comparisons and subjective well-being in a divided society. Journal of Economic Behavior \& Organization, 64(1): 69-90.

Knight, J., Song, L., \& Gunatilaka, R. (2009). Subjective well-being and its determinants in rural China. China Economic Review, 20(4): 635-649.

Krueger, A.B., \& Schkade, D.A. (2008). The reliability of subjective well-being measures. Journal of Public Economics, 92(8-9): 1833-1845.

Layte, R. (2012). The association between income inequality and mental health: Testing status anxiety, social capital, and neo-materialist explanations. European Sociological Review, 28(4): 498-511.

O'Donnell, G. (2013). Using well-being as a guide to public policy. In J. Helliwell, R. Layard, \& J. Sachs (eds). World Happiness Report 2013. New York: UN Sustainable Development Solutions Network.

Oishi, S., Kesebir, S, \& Diener, E. (2011). Income inequality and happiness. Psychological Science, 22 (9): 1095-1100.

Ott, J. (2005). Level and inequality of happiness in nations: Does greater happiness of a greater number imply greater inequality in happiness? Journal of Happiness Studies, 6: $397-420$.

Piketty, T. (2014). Capital in the twenty-first century. Cambridge: Harvard University Press.

Piketty, T., \& Saez, E. (2014). Inequality in the long run. Science, 344(6186): 838-843. 
Savolainen, J. (2000). Inequality, welfare state, and homocide: Further support for the institutional anomie theory. Criminology, 38(4): 1021-1042.

Schneider, S.M. (2015). Income inequality and subjective wellbeing: Trends, challenges, and research directions. Journal of Happiness Studies, doi:10.1007/s10902-015-9655-3.

Schwarze, J., \& Harpfer, M. (2007). Are people inequality averse, and do they prefer redistribution by the state? Evidence from German longitudinal data on life satisfaction. Journal of Socio-Economics, 36: 233-249.

Schyns, P. (2002). Wealth of nations, individual income and life satisfaction in 42 countries: A multilevel approach. Social Indicators Research, 60: 5-40.

Senik, C. (2009). Income distribution and subjective happiness: A survey. OECD Social Employment and Migration Working Papers, 96.

Stiglitz, J.E., Sen, A., \& Fitoussi, J-P. (2010). Mis-Measuring Our Lives. New York: The New Press.

Stone, A., \& Mackie, C. (2013). Subjective Well-Being: Measuring Happiness, Suffering, and Other Dimensions of Experience. Washington D.C.: The National Academies Press.

Thurow, L.C. (1971). The income distribution as a pure public good. Quarterly Journal of Economics, 85(2): 327-336.

Tomes, N. (1986). Income distribution, happiness and satisfaction: A direct test of the interdependent preferences model. Journal of Economic Psychology, 7: 425-446.

Veenhoven, R. (1995). The cross-national pattern of happiness of happiness. Social Indicators Research, 34: 33-36. 
Table 1: Summary statistics

\begin{tabular}{lcc}
\hline & Mean & St. Dev. \\
\hline BPL & 7.00 & $(1.89)$ \\
Enjoyment & 0.89 & $(0.32)$ \\
Happiness & 0.86 & $(0.35)$ \\
Stress & 0.38 & $(0.49)$ \\
Worry & 0.30 & $(0.46)$ \\
Self-reported health & 3.55 & $(1.10)$ \\
BPL in five years & 7.63 & $(2.20)$ \\
Satisfaction with city & 0.88 & $(0.33)$ \\
Asthma & 0.11 & $(0.31)$ \\
Cancer & 0.10 & $(0.29)$ \\
Depression & 0.16 & $(0.37)$ \\
Diabetes & 0.12 & $(0.32)$ \\
Heart attack & 0.05 & $(0.21)$ \\
High blood pressure & 0.34 & $(0.47)$ \\
High cholesterol & 0.31 & $(0.46)$ \\
BMI & 27.29 & $(5.59)$ \\
Smoke & 0.16 & $(0.37)$ \\
Exercise & 2.82 & $(2.40)$ \\
Healthy eating & 4.14 & $(2.53)$ \\
Median annual household & $\$ 54,000$ & - \\
income & 0.51 \\
Median ZIP-code income & $\$ 61,200$ & $(23,325.00)$ \\
Median MSA income & $\$ 54,083$ & $(10,098.00)$ \\
Median state income & $\$ 52,126$ & $(7,625.85)$ \\
ZIP-code Gini index & 0.43 & $(0.05)$ \\
MSA Gini index & 0.46 & $(0.02)$ \\
State Gini index & 0.47 & $(0.02)$ \\
Female & 0.5 & $(0.50)$ \\
Black & 0.1 & $(0.29)$ \\
White & 0.84 & $(0.36)$ \\
Age & 52.79 & $(17.74)$ \\
Married & 0.54 & $(0.50)$ \\
Did not complete high school & 0.05 & $(0.21)$ \\
High school graduate & 0.17 & $(0.38)$ \\
College degree & 0.25 & $(0.43)$ \\
Post graduate work or degree & 0.22 & $(0.41)$ \\
Children in household & 0.3 & $(0.46)$ \\
Employed in last 7 days & $(0.50)$ \\
Observations & & \\
& 0.519 & \\
& & \\
& & \\
& &
\end{tabular}


Table 2: Income inequality and SWB in large regions

\begin{tabular}{lcc}
\hline & MSA Gini & State Gini \\
& $(1)$ & $(2)$ \\
\hline BPL & $-1.079^{* * * *}$ & $-1.099^{* * * *}$ \\
& $(0.126)$ & $(0.180)$ \\
Enjoyment & 437,849 & 439,844 \\
& $-0.280^{* * * *}$ & $-0.372^{* * * *}$ \\
& $(0.023)$ & $(0.033)$ \\
Happiness & 437,051 & 439,041 \\
& $-0.225^{* * * *}$ & $-0.298^{* * * *}$ \\
& $(0.021)$ & $(0.029)$ \\
Stress & 436,878 & 438,870 \\
& $0.274^{* * * *}$ & $0.245^{* * * *}$ \\
& $(0.032)$ & $(0.044)$ \\
Worry & 437,374 & 439,368 \\
& $0.517^{* * * *}$ & $0.475^{* * * *}$ \\
& $(0.031)$ & $(0.045)$ \\
& 437,416 & 439,407 \\
\hline
\end{tabular}

Notes: Robust standard errors (clustered by ZIP code) in parenthesis. All models are estimated using OLS; ; condition on ZIP-code, MSA, and state median income; own income; gender (male or female); race (White, Black, Asian, Hispanic); age (and age-squared); marital status (never-married, married, divorced, separated, domestic partner), parental status (child under 18 living in household or not) \& employment status (employed in last seven days or not); education (less than high school, high school, technical school, some college, college, post-college); state; and day, month, \& year of interview fixed effects. $* * *, * * *, * * * *$ signify the coefficient is statistically significant at $\mathrm{p}<0.10$, $0.05,0.01,0.001$, respectively. 
Table 3: Income inequality and SWB in small regions

\begin{tabular}{lc}
\hline & ZIP-code Gini \\
& $0.794^{* * * *}$ \\
\hline BPL & $(0.057)$ \\
& 439,843 \\
Enjoyment & -0.009 \\
& $(0.011)$ \\
& 439,040 \\
Happiness & -0.008 \\
& $(0.010)$ \\
& 438,869 \\
Stress & $0.119 * * * *$ \\
& $(0.015)$ \\
& 439,367 \\
Worry & $0.177 * * * *$ \\
& $(0.015)$ \\
& 439,406 \\
\hline
\end{tabular}

Notes: Robust standard errors (clustered by ZIP code) in parenthesis. The model is estimated using OLS; ; condition on ZIP-code, MSA, and state median income; own income; gender (male or female); race (White, Black, Asian, Hispanic); age (and age-squared); marital status (never-married, married, divorced, separated, domestic partner), parental status (child under 18 living in household or not) \& employment status (employed in last seven days or not); education (less than high school, high school, technical school, some college, college, post-college); state; and day, month, \& year of interview fixed effects. $* * *, * * *, * * * *$ signify the coefficient is statistically significant at $\mathrm{p}<0.10,0.05,0.01,0.001$, respectively. 
Table 4: Gini-index correlation table

\begin{tabular}{lccc}
\hline & $\begin{array}{c}\text { ZIP-code } \\
\text { Gini index } \\
(1)\end{array}$ & $\begin{array}{c}\text { MSA } \\
\text { Gini index } \\
(2)\end{array}$ & $\begin{array}{c}\text { State } \\
\text { Gini index } \\
(3)\end{array}$ \\
\hline ZIP-code Gini index & 1.0000 & & \\
MSA Gini index & 0.2102 & 1.0000 & \\
State Gini index & 0.1666 & 0.4685 & 1.0000 \\
\hline
\end{tabular}

Notes: Spearman correlations. The p-value for each is 0.00 . 
Table 5: Multi-scale model

\begin{tabular}{|c|c|c|c|c|}
\hline & $\begin{array}{l}\text { ZIP-code Gini } \\
(1)\end{array}$ & $\begin{array}{l}\text { MSA Gini } \\
\text { (2) }\end{array}$ & $\begin{array}{c}\text { State Gini } \\
\text { (3) }\end{array}$ & $\begin{array}{l}\text { Net relation. } \\
\text { (4) }\end{array}$ \\
\hline $\begin{array}{l}\mathrm{BPL} \\
\mathrm{n}=437,848\end{array}$ & $\begin{array}{l}1.027^{* * * *} \\
(0.059)\end{array}$ & $\begin{array}{l}-1.489 * * * * \\
(0.145)\end{array}$ & $\begin{array}{l}-0.725^{* * * *} \\
(0.196)\end{array}$ & $\begin{array}{l}-0.590 \text { **** } \\
(0.083)\end{array}$ \\
\hline $\begin{array}{l}\text { Enjoyment } \\
\qquad \mathrm{n}=437,050\end{array}$ & $\begin{array}{l}0.037^{* * * * *} \\
(0.011)\end{array}$ & $\begin{array}{l}-0.235^{* * * *} \\
(0.027)\end{array}$ & $\begin{array}{l}-0.248^{* * * *} \\
(0.037)\end{array}$ & $\begin{array}{l}-0.209 * * * * \\
(0.016)\end{array}$ \\
\hline $\begin{array}{l}\text { Happiness } \\
\qquad \mathrm{n}=436,877\end{array}$ & $\begin{array}{l}0.028 * * * \\
(0.010)\end{array}$ & $\begin{array}{l}-0.191 * * * * \\
(0.024)\end{array}$ & $\begin{array}{l}-0.201 * * * * \\
(0.033)\end{array}$ & $\begin{array}{l}-0.170 * * * * \\
(0.014)\end{array}$ \\
\hline $\begin{array}{l}\text { Stress } \\
\qquad \mathrm{n}=437,373\end{array}$ & $\begin{array}{l}0.089 * * * * \\
(0.015)\end{array}$ & $\begin{array}{l}0.211 \text { ***** } \\
(0.036)\end{array}$ & $\begin{array}{c}0.058 \\
(0.050)\end{array}$ & $\begin{array}{l}0.163 * * * * \\
(0.021)\end{array}$ \\
\hline $\begin{array}{l}\text { Worry } \\
\qquad \mathrm{n}=437,415\end{array}$ & $\begin{array}{l}0.116^{* * * * *} \\
(0.015)\end{array}$ & $\begin{array}{l}0.421 * * * * \\
(0.035)\end{array}$ & $\begin{array}{l}0.143 \text { *** } \\
(0.049)\end{array}$ & $\begin{array}{l}0.311^{* * * *} \\
(0.021)\end{array}$ \\
\hline
\end{tabular}

Notes: Robust standard errors (clustered by ZIP code) in parenthesis. All models are estimated using OLS; ; condition on ZIP-code, MSA, and state median income; own income; gender (male or female); race (White, Black, Asian, Hispanic); age (and age-squared); marital status (never-married, married, divorced, separated, domestic partner), parental status (child under 18 living in household or not) \& employment status (employed in last seven days or not); education (less than high school, high school, technical school, some college, college, post-college); state; and day, month, \& year of interview fixed effects. *, **,***,*** signify the coefficient is statistically significant at $\mathrm{p}<0.10$, $0.05,0.01,0.001$, respectively. 
Table 6: Other measures of well-being

\begin{tabular}{|c|c|c|c|c|}
\hline & $\begin{array}{l}\text { ZIP-code Gini } \\
\text { (1) }\end{array}$ & $\begin{array}{l}\text { MSA Gini } \\
\text { (2) }\end{array}$ & $\begin{array}{l}\text { State Gini } \\
\text { (3) }\end{array}$ & $\begin{array}{l}\text { Net relation. } \\
\text { (3) }\end{array}$ \\
\hline Self-reported health & $0.864^{* * * *}$ & $-0.526^{* * * *}$ & $-0.620 * * * *$ & $-0.166^{* * *}$ \\
\hline $\mathrm{n}=437,508$ & $(0.035)$ & $(0.081)$ & $(0.112)$ & $(0.048)$ \\
\hline BPL in five years & 0.830 **** & -0.258 & -0.042 & $0.214^{* *}$ \\
\hline $\mathrm{n}=420,908$ & $(0.066)$ & $(0.162)$ & $(0.215)$ & $(0.093)$ \\
\hline Satisfaction with city & $0.184^{* * * *}$ & $-0.271^{* * * *}$ & $-0.623^{* * * *}$ & $-0.339 * * * *$ \\
\hline $\mathrm{n}=436,409$ & $(0.014)$ & $(0.037)$ & $(0.051)$ & $(0.019)$ \\
\hline High blood pressure & $-0.262 * * * *$ & 0.002 & $0.272 * * * *$ & 0.017 \\
\hline $\mathrm{n}=437,157$ & $(0.014)$ & $(0.034)$ & $(0.047)$ & $(0.019)$ \\
\hline High cholesterol & $-0.140^{* * * *}$ & $0.054^{*}$ & $0.242 * * * *$ & $0.079 * * * *$ \\
\hline $\mathrm{n}=436,651$ & $(0.014)$ & $(0.033)$ & $(0.046)$ & $(0.019)$ \\
\hline Diabetes & $-0.191^{* * * *}$ & 0.014 & $0.090 * * *$ & $-0.033^{* *}$ \\
\hline $\mathrm{n}=437,292$ & $(0.009)$ & $(0.024)$ & $(0.031)$ & $(0.013)$ \\
\hline Depression & $0.024^{* *}$ & $-0.158 * * * *$ & $-0.143^{* * * *}$ & $-0.130 * * * *$ \\
\hline $\mathrm{n}=437,351$ & $(0.012)$ & $(0.028)$ & $(0.039)$ & $(0.017)$ \\
\hline Heart attack & $-0.067 * * * *$ & -0.005 & $0.055^{* * *}$ & -0.005 \\
\hline $\mathrm{n}=437,423$ & $(0.006)$ & $(0.015)$ & $(0.021)$ & $(0.009)$ \\
\hline Asthma & -0.012 & $-0.113^{* * * *}$ & $0.066^{* *}$ & $-0.026^{*}$ \\
\hline $\mathrm{n}=437,425$ & $(0.010)$ & $(0.024)$ & $(0.033)$ & $(0.014)$ \\
\hline Cancer & 0.009 & $-0.043^{* *}$ & $0.063 * *$ & 0.013 \\
\hline $\mathrm{n}=437,285$ & $(0.009)$ & $(0.021)$ & $(0.028)$ & $(0.012)$ \\
\hline Smoking & $-0.077^{* * * *}$ & 0.008 & $0.141^{* * * *}$ & $0.036^{* *}$ \\
\hline $\mathrm{n}=437,653$ & $(0.012)$ & $(0.029)$ & $(0.041)$ & $(0.018)$ \\
\hline BMI & $-7.134^{* * * *}$ & $-1.386^{* * *}$ & $-1.208^{*}$ & $-4.239 * * * *$ \\
\hline $\mathrm{n}=426,219$ & $(0.193)$ & $(0.453)$ & $(0.648)$ & $(0.274)$ \\
\hline Exercise & $1.073^{* * * *}$ & $-2.558^{* * * *}$ & -0.328 & $-0.878^{* * * *}$ \\
\hline $\mathrm{n}=436,104$ & $(0.082)$ & $(0.200)$ & $(0.270)$ & $(0.118)$ \\
\hline Healthy eating & $0.330^{* * * *}$ & $-1.139 * * * *$ & $2.143^{* * * *}$ & $0.617^{* * * *}$ \\
\hline $\mathrm{n}=433,702$ & $(0.083)$ & $(0.192)$ & $(0.267)$ & $(0.112)$ \\
\hline
\end{tabular}

Notes: Robust standard errors (clustered by ZIP code) in parenthesis. All models are estimated using OLS; condition on ZIP-code, MSA, and state median income; own income; gender (male or female); race (White, Black, Asian, Hispanic); age (and age-squared); marital status (never-married, married, divorced, separated, domestic partner), parental status (child under 18 living in household or not) \& employment status (employed in last seven days or not); education (less than high school, high school, technical school, some college, college, post-college); state; and day, month, \& year of interview fixed effects. $*, * *, * * *, * * * *$ signify the coefficient is statistically significant at $\mathrm{p}<0.10,0.05,0.01,0.001$, respectively. 
Table 7: Subgroups

\begin{tabular}{|c|}
\hline $\begin{array}{c}\text { Bottom and top ZIP-code Gini-index quartiles } \\
(\text { Gini }<0.390 \text { and Gini }>0.455)\end{array}$ \\
\hline $\begin{array}{c}\text { Bottom and top MSA Gini-index quartiles } \\
(\text { Gini }<0.445 \text { and Gini }>0.476)\end{array}$ \\
\hline $\begin{array}{c}\text { Bottom and top ZIP-code median-income quartiles } \\
\text { (inc. }<\$ 44,730 \text { and inc. }>\$ 73,193)\end{array}$ \\
\hline $\begin{array}{c}\text { Bottom and top MSA median-income quartiles } \\
\text { (inc. }<\$ 46,648 \text { and inc. }>\$ 59,261)\end{array}$ \\
\hline $\begin{array}{c}\text { Bottom and top own-income quartiles } \\
\text { (inc. }<\$ 24,000 \text { and inc. }>\$ 90,000)\end{array}$ \\
Race \\
$($ whites and blacks) \\
Education \\
(ed. $\leq$ high school completion and ed. $\geq$ college completion) $)$ \\
Marital status \\
married and unmarried \\
Gender \\
female and male \\
Parental status \\
parents and non-parents \\
\hline $\begin{array}{c}\text { Bottom and top age quartiles } \\
(\text { age }<40 \text { and age }>67)\end{array}$ \\
\hline
\end{tabular}


Table 8: Subgroup analyses

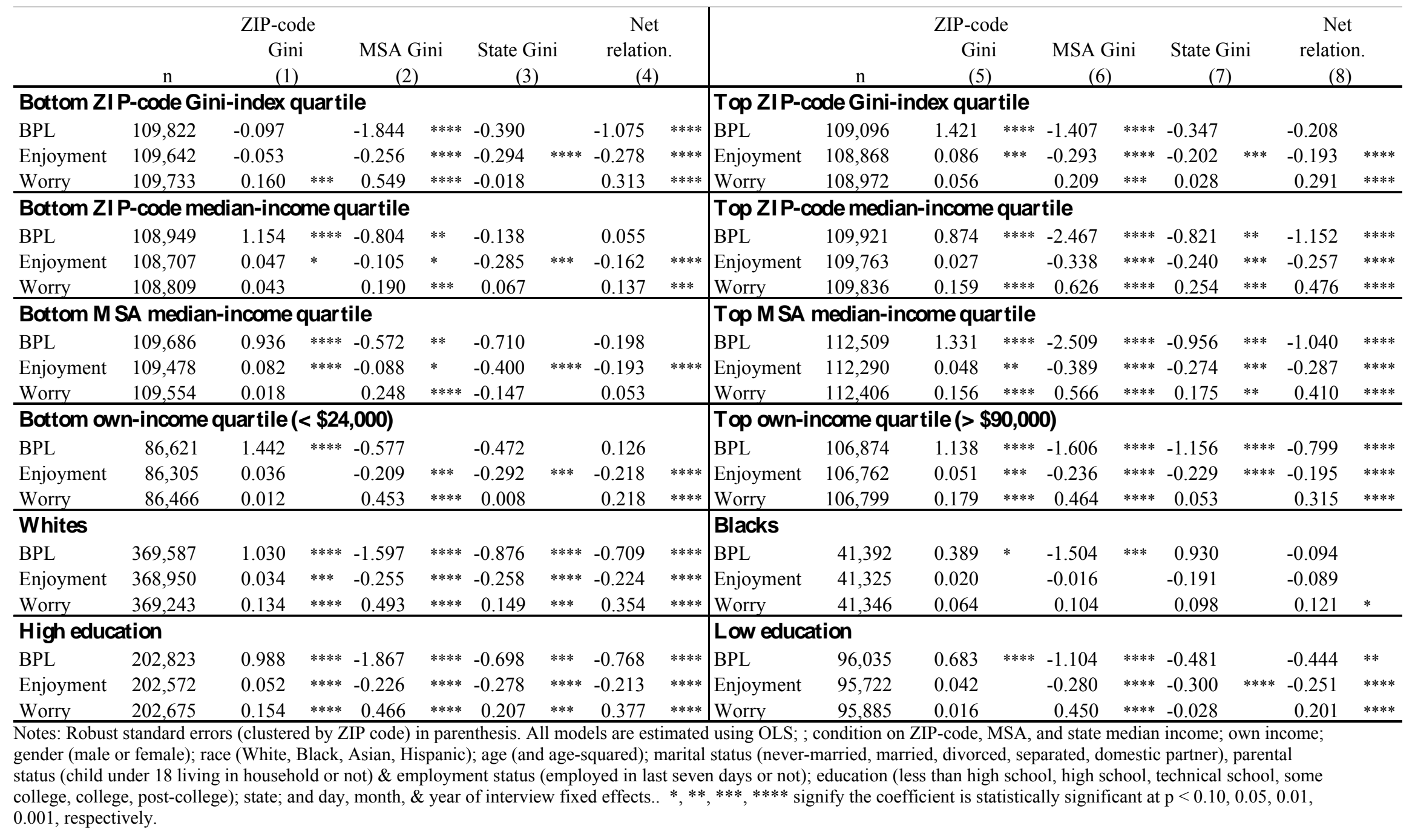


Table 9a. Specifications with alternate measures of income inequality

\begin{tabular}{|c|c|c|c|c|c|c|c|c|}
\hline & \multicolumn{2}{|c|}{$\begin{array}{l}\text { ZIP-code Gini } \\
(1)\end{array}$} & \multicolumn{2}{|c|}{$\begin{array}{l}\text { MSA Gini } \\
\text { (2) }\end{array}$} & \multicolumn{2}{|c|}{$\begin{array}{c}\text { State Gini } \\
(3)\end{array}$} & \multicolumn{2}{|c|}{$\begin{array}{c}\text { Net relation. } \\
\text { (4) }\end{array}$} \\
\hline \multicolumn{9}{|c|}{ Income share of bottom quintile } \\
\hline $\begin{array}{l}\text { BPL } \\
\qquad n=434,445\end{array}$ & $\begin{array}{r}-0.050 \\
(0.003)\end{array}$ & $* * * *$ & $\begin{array}{l}0.075 \\
(0.008)\end{array}$ & $* * * *$ & $\begin{array}{l}0.029 \\
(0.012)\end{array}$ & $* *$ & $\begin{array}{l}0.146 \\
(0.035)\end{array}$ & $* * * *$ \\
\hline $\begin{array}{l}\text { Enjoyment } \\
\qquad \mathrm{n}=433,660\end{array}$ & $\begin{array}{r}-0.001 \\
(0.001)\end{array}$ & $* *$ & $\begin{array}{l}0.013 \\
(0.002)\end{array}$ & $* * * *$ & $\begin{array}{l}0.012 \\
(0.002)\end{array}$ & $* * * *$ & $\begin{array}{l}0.077 \\
(0.006)\end{array}$ & $* * * *$ \\
\hline $\begin{array}{l}\text { Happiness } \\
\qquad \mathrm{n}=433,481\end{array}$ & $\begin{array}{r}-0.002 \\
(0.001)\end{array}$ & $* * *$ & $\begin{array}{l}0.012 \\
(0.001)\end{array}$ & $* * * *$ & $\begin{array}{l}0.010 \\
(0.002)\end{array}$ & $* * * *$ & $\begin{array}{l}0.066 \\
(0.006)\end{array}$ & $* * * *$ \\
\hline $\begin{array}{l}\text { Stress } \\
\qquad \mathrm{n}=433,976\end{array}$ & $\begin{array}{r}-0.006 \\
(0.001)\end{array}$ & $* * * *$ & $\begin{array}{r}-0.010 \\
(0.002)\end{array}$ & $* * * *$ & $\begin{array}{r}-0.001 \\
(0.003)\end{array}$ & & $\begin{array}{r}-0.062 \\
(0.009)\end{array}$ & $* * * *$ \\
\hline $\begin{array}{l}\text { Worry } \\
\qquad \mathrm{n}=434,018\end{array}$ & $\begin{array}{r}-0.007 \\
(0.001) \\
\end{array}$ & $* * * *$ & $\begin{array}{r}-0.020 \\
(0.002) \\
\end{array}$ & $* * * *$ & $\begin{array}{r}-0.006 \\
(0.003) \\
\end{array}$ & $* *$ & $\begin{array}{r}-0.115 \\
(0.009) \\
\end{array}$ & $* * * *$ \\
\hline \multicolumn{9}{|c|}{ Income share of top quintile } \\
\hline $\begin{array}{l}\text { BPL } \\
\qquad n=434,445\end{array}$ & $\begin{array}{r}0.012 \\
(0.001)\end{array}$ & $* * * *$ & $\begin{array}{r}-0.017 \\
(0.002)\end{array}$ & $* * * *$ & $\begin{array}{l}-0.009 \\
(0.002)\end{array}$ & $* * * *$ & $\begin{array}{r}-0.726 \\
(0.102)\end{array}$ & $* * * *$ \\
\hline $\begin{array}{l}\text { Enjoyment } \\
\qquad \mathrm{n}=433,660\end{array}$ & $\begin{array}{l}0.000 \\
(0.000)\end{array}$ & $* * *$ & $\begin{array}{r}-0.002 \\
(0.000)\end{array}$ & $* * * *$ & $\begin{array}{r}-0.003 \\
(0.000)\end{array}$ & $* * * *$ & $\begin{array}{r}-0.248 \\
(0.019)\end{array}$ & $* * * *$ \\
\hline $\begin{array}{l}\text { Happiness } \\
\qquad \mathrm{n}=433,481\end{array}$ & $\begin{array}{l}0.000 \\
(0.000)\end{array}$ & $* * *$ & $\begin{array}{r}-0.002 \\
(0.000)\end{array}$ & $* * * *$ & $\begin{array}{r}-0.002 \\
(0.000)\end{array}$ & $* * * *$ & $\begin{array}{r}-0.200 \\
(0.017)\end{array}$ & $* * * *$ \\
\hline $\begin{array}{l}\text { Stress } \\
\qquad \mathrm{n}=433,976\end{array}$ & $\begin{array}{l}0.001 \\
(0.000)\end{array}$ & $* * * *$ & $\begin{array}{l}0.002 \\
(0.000)\end{array}$ & $* * * *$ & $\begin{array}{l}0.001 \\
(0.001)\end{array}$ & & $\begin{array}{l}0.195 \\
(0.026)\end{array}$ & $* * * *$ \\
\hline $\begin{array}{l}\text { Worry } \\
\qquad n=434,018\end{array}$ & $\begin{array}{l}0.001 \\
(0.000) \\
\end{array}$ & $* * * *$ & $\begin{array}{l}0.005 \\
(0.000) \\
\end{array}$ & $* * * *$ & $\begin{array}{r}0.002 \\
(0.001) \\
\end{array}$ & $* * *$ & $\begin{array}{l}0.385 \\
(0.026) \\
\end{array}$ & $* * * *$ \\
\hline \multicolumn{9}{|c|}{ Income share of top five percent } \\
\hline $\begin{array}{l}\text { BPL } \\
\qquad n=434,445\end{array}$ & $\begin{array}{r}0.013 \\
(0.001)\end{array}$ & $* * * *$ & $\begin{array}{r}-0.015 \\
(0.002)\end{array}$ & $* * * *$ & $\begin{array}{r}-0.015 \\
(0.003)\end{array}$ & $* * * *$ & $\begin{array}{r}-0.403 \\
(0.055)\end{array}$ & $* * * *$ \\
\hline $\begin{array}{l}\text { Enjoyment } \\
\qquad \mathrm{n}=433,660\end{array}$ & $\begin{array}{l}0.001 \\
(0.000)\end{array}$ & $* * * *$ & $\begin{array}{r}-0.002 \\
(0.000)\end{array}$ & $* * * *$ & $\begin{array}{r}-0.004 \\
(0.001)\end{array}$ & $* * * *$ & $\begin{array}{r}-0.127 \\
(0.010)\end{array}$ & $* * * *$ \\
\hline $\begin{array}{l}\text { Happiness } \\
\qquad \mathrm{n}=433,481\end{array}$ & $\begin{array}{l}0.000 \\
(0.000)\end{array}$ & $* * *$ & $\begin{array}{r}-0.001 \\
(0.000)\end{array}$ & $* * * *$ & $\begin{array}{r}-0.003 \\
(0.000)\end{array}$ & $* * * *$ & $\begin{array}{r}-0.100 \\
(0.009)\end{array}$ & $* * * *$ \\
\hline $\begin{array}{l}\text { Stress } \\
\qquad \mathrm{n}=433,976\end{array}$ & $\begin{array}{l}0.001 \\
(0.000)\end{array}$ & $* * * *$ & $\begin{array}{l}0.002 \\
(0.000)\end{array}$ & $* * * *$ & $\begin{array}{l}0.002 \\
(0.001)\end{array}$ & $* * *$ & $\begin{array}{l}0.101 \\
(0.014)\end{array}$ & $* * * *$ \\
\hline $\begin{array}{l}\text { Worry } \\
\qquad n=434,018\end{array}$ & $\begin{array}{l}0.001 \\
(0.000) \\
\end{array}$ & $* * * *$ & $\begin{array}{r}0.004 \\
(0.000) \\
\end{array}$ & $* * * *$ & $\begin{array}{r}0.004 \\
(0.001) \\
\end{array}$ & $* * * *$ & $\begin{array}{l}0.196 \\
(0.014) \\
\end{array}$ & $* * * *$ \\
\hline
\end{tabular}

Notes: Robust standard errors (clustered by ZIP code) in parenthesis. All models are estimated using OLS; ; condition on ZIP-code, MSA, and state median income; own income; gender (male or female); race (White, Black, Asian, Hispanic); age (and age-squared); marital status (never-married, married, divorced, separated, domestic partner), parental status (child under 18 living in household or not) \& employment status (employed in last seven days or not); education (less than high school, high school, technical school, some college, college, post-college); state; and day, month, \& year of interview fixed effects.. *,**,***,**** signify the coefficient is statistically significant at $\mathrm{p}<0.10$, $0.05,0.01,0.001$, respectively. 
Table 9b. Additional specifications

\begin{tabular}{|c|c|c|c|c|c|c|c|c|}
\hline & \multicolumn{2}{|c|}{$\begin{array}{l}\text { ZIP-code Gini } \\
\text { (1) }\end{array}$} & \multicolumn{2}{|c|}{$\begin{array}{l}\text { MSA Gini } \\
\text { (2) }\end{array}$} & \multicolumn{2}{|c|}{$\begin{array}{c}\text { State Gini } \\
\text { (3) }\end{array}$} & \multicolumn{2}{|c|}{$\begin{array}{l}\text { Net relation. } \\
\text { (4) }\end{array}$} \\
\hline \multicolumn{9}{|c|}{ Include unemployment and poverty rates } \\
\hline $\begin{array}{l}\text { BPL } \\
\qquad n=437,723\end{array}$ & $\begin{array}{r}0.957 \\
(0.061)\end{array}$ & $* * * *$ & $\begin{array}{r}-1.383 \\
(0.151)\end{array}$ & $* * * *$ & $\begin{array}{r}-1.257 \\
(0.265)\end{array}$ & $* * * *$ & $\begin{array}{r}-0.820 \\
(0.116)\end{array}$ & $* * * *$ \\
\hline $\begin{array}{l}\text { Enjoyment } \\
\qquad \mathrm{n}=436,925\end{array}$ & $\begin{array}{l}0.036 \\
(0.011)\end{array}$ & $* * *$ & $\begin{array}{r}-0.198 \\
(0.029)\end{array}$ & $* * * *$ & $\begin{array}{r}-0.410 \\
(0.050)\end{array}$ & $* * * *$ & $\begin{array}{r}-0.268 \\
(0.022)\end{array}$ & $* * * *$ \\
\hline $\begin{array}{l}\text { Happiness } \\
\qquad \mathrm{n}=436,752\end{array}$ & $\begin{array}{l}0.030 \\
(0.010)\end{array}$ & $* * * *$ & $\begin{array}{l}-0.164 \\
(0.026)\end{array}$ & $* * * *$ & $\begin{array}{r}-0.345 \\
(0.045)\end{array}$ & $* * * *$ & $\begin{array}{r}-0.224 \\
(0.020)\end{array}$ & $* * * *$ \\
\hline $\begin{array}{l}\text { Stress } \\
\qquad \mathrm{n}=437,248\end{array}$ & $\begin{array}{l}0.095 \\
(0.016)\end{array}$ & $* * * *$ & $\begin{array}{l}0.205 \\
(0.039)\end{array}$ & $* * * *$ & $\begin{array}{l}0.088 \\
(0.069)\end{array}$ & & $\begin{array}{l}0.176 \\
(0.030)\end{array}$ & $* * * *$ \\
\hline $\begin{array}{l}\text { Worry } \\
\qquad n=437,290\end{array}$ & $\begin{array}{l}0.115 \\
(0.015) \\
\end{array}$ & $* * * *$ & $\begin{array}{r}0.410 \\
(0.038)\end{array}$ & $* * * *$ & $\begin{array}{l}0.028 \\
(0.068)\end{array}$ & & $\begin{array}{l}0.251 \\
(0.030) \\
\end{array}$ & $* * * *$ \\
\hline \multicolumn{9}{|c|}{$\geq 30$ respondents in $\mathrm{ZIP}$ code } \\
\hline $\begin{array}{l}\mathrm{BPL} \\
\qquad \mathrm{n}=359,069\end{array}$ & $\begin{array}{r}1.192 \\
(0.068)\end{array}$ & $* * * *$ & $\begin{array}{r}-1.554 \\
(0.163)\end{array}$ & $* * * *$ & $\begin{array}{r}-0.767 \\
(0.220)\end{array}$ & $* * * *$ & $\begin{array}{r}-0.569 \\
(0.092)\end{array}$ & $* * * *$ \\
\hline $\begin{array}{l}\text { Enjoyment } \\
\qquad \mathrm{n}=358,429\end{array}$ & $\begin{array}{l}0.040 \\
(0.013)\end{array}$ & $* * *$ & $\begin{array}{r}-0.231 \\
(0.031)\end{array}$ & $* * * *$ & $\begin{array}{r}-0.265 \\
(0.042)\end{array}$ & $* * * *$ & $\begin{array}{r}-0.213 \\
(0.017)\end{array}$ & $* * * *$ \\
\hline $\begin{array}{l}\text { Happiness } \\
\qquad \mathrm{n}=358,273\end{array}$ & $\begin{array}{l}0.028 \\
(0.011)\end{array}$ & $* *$ & $\begin{array}{r}-0.204 \\
(0.027)\end{array}$ & $* * * *$ & $\begin{array}{r}-0.181 \\
(0.037)\end{array}$ & $* * * *$ & $\begin{array}{l}-0.167 \\
(0.015)\end{array}$ & $* * * *$ \\
\hline $\begin{array}{l}\text { Stress } \\
\qquad \mathrm{n}=358,696\end{array}$ & $\begin{array}{l}0.093 \\
(0.018)\end{array}$ & $* * * *$ & $\begin{array}{l}0.187 \\
(0.041)\end{array}$ & $* * * *$ & $\begin{array}{l}0.072 \\
(0.056)\end{array}$ & & $\begin{array}{l}0.160 \\
(0.024)\end{array}$ & $* * * *$ \\
\hline $\begin{array}{l}\text { Worry } \\
\qquad \mathrm{n}=358,722\end{array}$ & $\begin{array}{l}0.119 \\
(0.017) \\
\end{array}$ & $* * * *$ & $\begin{array}{r}0.410 \\
(0.040) \\
\end{array}$ & $* * * *$ & $\begin{array}{r}0.139 \\
(0.055)\end{array}$ & ** & $\begin{array}{l}0.305 \\
(0.024) \\
\end{array}$ & $* * * *$ \\
\hline \multicolumn{9}{|c|}{$\geq 60$ respondents in $Z I P$ code } \\
\hline $\begin{array}{l}\mathrm{BPL} \\
\qquad \mathrm{n}=232,188\end{array}$ & $\begin{array}{r}1.082 \\
(0.087)\end{array}$ & $* * * *$ & $\begin{array}{r}-1.462 \\
(0.209)\end{array}$ & $* * * *$ & $\begin{array}{l}-0.721 \\
(0.274)\end{array}$ & $* * *$ & $\begin{array}{r}-0.553 \\
(0.114)\end{array}$ & $* * * *$ \\
\hline $\begin{array}{l}\text { Enjoyment } \\
\qquad \mathrm{n}=231,791\end{array}$ & $\begin{array}{l}0.035 \\
(0.016)\end{array}$ & $* *$ & $\begin{array}{r}-0.231 \\
(0.039)\end{array}$ & $* * * *$ & $\begin{array}{r}-0.241 \\
(0.052)\end{array}$ & $* * * *$ & $\begin{array}{r}-0.204 \\
(0.021)\end{array}$ & $* * * *$ \\
\hline $\begin{array}{l}\text { Happiness } \\
\qquad \mathrm{n}=231,722\end{array}$ & $\begin{array}{l}0.019 \\
(0.014)\end{array}$ & & $\begin{array}{r}-0.176 \\
(0.034)\end{array}$ & $* * * *$ & $\begin{array}{r}-0.163 \\
(0.045)\end{array}$ & $* * * *$ & $\begin{array}{r}-0.149 \\
(0.019)\end{array}$ & $* * * *$ \\
\hline $\begin{array}{l}\text { Stress } \\
\qquad \mathrm{n}=231,947\end{array}$ & $\begin{array}{l}0.119 \\
(0.023)\end{array}$ & $* * * *$ & $\begin{array}{l}0.187 \\
(0.052)\end{array}$ & $* * * *$ & $\begin{array}{l}0.064 \\
(0.068)\end{array}$ & & $\begin{array}{l}0.167 \\
(0.029)\end{array}$ & $* * * *$ \\
\hline $\begin{array}{l}\text { Worry } \\
\qquad n=231,969\end{array}$ & $\begin{array}{l}0.167 \\
(0.022)\end{array}$ & $* * * *$ & $\begin{array}{r}0.339 \\
(0.050) \\
\end{array}$ & $* * * *$ & $\begin{array}{r}0.118 \\
(0.068)\end{array}$ & $*$ & $\begin{array}{l}0.283 \\
(0.029)\end{array}$ & $* * * *$ \\
\hline
\end{tabular}

Notes: Robust standard errors (clustered by ZIP code) in parenthesis. All models are estimated using OLS; ; condition on ZIP-code, MSA, and state median income; own income; gender (male or female); race (White, Black, Asian, Hispanic); age (and age-squared); marital status (never-married, married, divorced, separated, domestic partner), parental status (child under 18 living in household or not) \& employment status (employed in last seven days or not); education (less than high school, high school, technical school, some college, college, post-college); state; and day, month, \& year of interview fixed effects.. *,**,***,*** signify the coefficient is statistically significant at $\mathrm{p}<0.10$, $0.05,0.01,0.001$, respectively. 